\title{
RUMAH-RUMAH TAHFIZH DI KOTA BANJARMASIN: PROFIL, PROGRAM, DAN METODE PENGAJARAN AL-QUR'AN
}

\author{
Muhammad Arobi \\ Prodi Ilmu Al-Quran dan Tafsir \\ Universitas Islam Negeri Antasari \\ E-mail : m.arobi@uin-antasari.ac.id
}

\author{
Website : https://jurnal.uin-antasari.ac.id/index.php/itjik/index \\ Received: Mei 2019; Accepted: Juli 2019; Published: Agustus 2019
}

\begin{abstract}
In Banjarmasin, there are many tahfizh houses with various methods of teaching Al-Qur'an. In this paper a summary of the profiles, programs, and methods of tahfizh houses in Banjarmasin is summarized briefly. This type of research is a qualitative field research. The subject of this research is tahfizh houses in Banjarmasin city in 2018 which have been established for more than one year. The object of this research is the profile, program, and variant of the Qur'an teaching method in each tahfizh house. The data needed in this study is data obtained from the results of observations, interviews, and documentation. The collected data is collected and edited and classified according to the research needs and described according to what is in the field. The results of the study show that there are several tahfizh houses in the city of Banjarmasin in 2018 which have been established for more than one year and have more than fifty students. The tahfizh houses have scheduled Qur'anic learning programs that have been scheduled, there are three meetings every one week, there are four meetings, and there are five meetings. All the Tahfizh houses above each have a method in the teaching of the Qur'an.
\end{abstract}

Keywords: tahfizh houses; teaching program of Al-Qur'an; teaching method of Al-Qur'an

\begin{abstract}
ABSTRAK
Di Kota Banjarmasin, ada banyak rumah-rumah tahfizh dengan bearagam metode pengajaran al-Qur'an. Dalam tulisan ini dipaparkan secara ringkas profil, program, dan metode rumahrumah tahfizh yang ada di kota Banjarmasin. Jenis penelitian ini merupakan penelitian lapangan yang bersifat kualitatif. Subjek penelitian ini adalah rumah-rumah tahfizh yang ada di kota Banjarmasin tahun 2018 yang telah berdiri lebih dari satu tahun. Objek penelitian ini ialah profil, program, dan varian metode pengajaran al-Qur'an di masing-masing rumah tahfizh. Data yang diperlukan dalam penelitian ini ialah data yang diperoleh dari hasil observasi, wawancara,serta dokumentasi. Data yang terkumpul dikoleksi dan diedit serta diklasifikasikan sesuai dengan kebutuhan penelitian dan dideskripsikan sesuai dengan yang ada di lapangan. Hasil penelitian menunjukkan bahwa ada beberapa rumah tahfizh di kota Banjarmasin pada tahun 2018 yang sudah berdiri lebih dari satu tahun dan mempunyai santri lebih dari lima puluh orang. Rumah-rumah tahfizh tersebut mempunyai program pembelajaran al-Qur'an yang sudah terjadwal, ada yang tiga kali pertemuan setiap satu minggu, ada yang empat kali pertemuan, dan ada yang lima kali pertemuan. Semua rumah tahfizh di atas, masingmasing mempunyai metode dalam pengajaran al-Qur'an.
\end{abstract}

Kata kunci : rumah tahfizh; program pengajaran Al-Qur'an; metode pengajaran Al-Qur'an

\section{PENDAHULUAN}

Al-Qur'an adalah kitab suci umat

Islam. Oleh karena itu, umat Islam diperintahkan untuk mengagungkan al-
Qur'an, membaca dan mempelajarinya, serta mengamalkan ajaran-ajaran yang dikandungnya. Terkait dengan membaca alQur'an, ada aturan yang harus dilaksanakan, 
yaitu membacanya harus sesuai dengan bacaan yang disampaikan oleh Nabi Saw kepada para sahabatnya. Selanjutnya para sahabat menyampaikan al-Qur'an kepada generasi sesudahnya (tabi' in) dengan bacaan yang diajarkan oleh Nabi. Begitulah seterusnya sampai sekarang. Oleh karena itu, diwajibkan bagi umat Islam untuk belajar membaca al-Qur'an kepada guru yang mempunyai bacaan al-Qur'an yang baik dan benar sebagaimana bacaan Nabi Saw dan generasi sesudahnya.

Dalam rangka pembelajaran alQur'an, umat Islam banyak membangun sekolah-sekolah al-Qur'an. Di Indonesia, ada banyak sekali Taman Kanak-Kanak (TK) al-Qur'an dan Taman Pendidikan alQur'an (TPA). Selain banyaknya sekolahsekolah al-Qur'an, di beberapa daerah, pembelajaran al-Qur'an juga mendapat perhatian dari pimpinan daerah dan didukung dengan perda, seperti pemerintah Provinsi Kalimantan Selatan yang mengeluarkan peraturan Daerah Provinsi Kalimantan Selatan Nomor 3 tahun 2009 tentang pendidikan al-Qur'an di Kalimantan Selatan pada Bab II Pasal 3 yang berbunyi "Pendidikan al-Qur'an bertujuan agar setiap peserta didik dapat membaca dan menulis huruf-huruf al-Qur'an secara baik dan benar. serta dapat memahami, menghayati, dan mengamalkan isi al-Qur'an (Dinas Pendidikan Kalimantan Selatan, 2010).

Dalam beberapa tahun terakhir, khususnya di kota Banjarmasin, pembelajaran al-Qur'an mengalami perkembangan, yaitu pembelajaran alQur'an tidak hanya sampai membaca alQur'an, tapi juga menghafal al-Qur'an. Ada banyak lembaga atau sekolah tahfizh alQur'an di kota Banjarmasin. Sekolah tahfizh tersebut tidak mengharuskan para murid untuk menetap di asrama seperti di pesantren. Pembelajaran al-Qur'an hanya berlangsung satu hingga dua jam dalam sehari. Lembaga tahfizh ini dikenal dengan istilah rumah tahfizh. Rumah-rumah tahfizh banyak diminati para murid khususnya dari kalangan anak-anak. Di Kota Banjarmasin, ada banyak rumah-rumah tahfizh dengan bearagam metode pengajaran al-Qur'an. Dalam tulisan ini dipaparkan secara ringkas profil, program, dan metode rumah-rumah tahfizh yang ada di kota Banjarmasin.

\section{METODE PENELITIAN}

Jenis penelitian ini merupakan penelitian lapangan yang bersifat kualitatif. Subjek penelitian ini adalah rumah-rumah tahfizh yang ada di kota Banjarmasin tahun 2018 yang telah berdiri lebih dari satu tahun, memiliki lebih dari lima puluh santri, dan memiliki struktur kepengurusan, program dan metode pengajaran al-Qur'an. Adapun objek yang dibahas dalam penelitian ini ialah profil, program, dan varian metode pengajaran al-Qur'an di masing-masing rumah tahfizh.

Data yang diperlukan dalam penelitian ini ialah data yang diperoleh dari hasil observasi dan wawancara dengan responden dan informan, yaitu para ustadz, ustadzah, dan para pengurus masing-masing rumah tahfizh, serta dokumentasi.

Data yang terkumpul dikoleksi dan diedit serta diklasifikasikan sesuai dengan kebutuhan penelitian dan dideskripsikan sesuai dengan yang ada di lapangan.

\section{HASIL DAN PEMBAHASAN}

\section{Metode Pengajaran Al-Qur'an}

Sejak awal mula pengajaran alQur'an hingga kini, ada banyak metode yang digunakan dalam pembelajaran al-Qur'an. Dari yang tradisional seperti metode Jibril as (talaqqî) dan ejaan (al-Baghdâdiyyah) hingga yang modern seperti metode ummi, qiraati, dan tartili. Hal itu merupakan hasil dari usaha para cendekiawan muslim yang terus mengembangkan metode pengajaran al-Qur'an agar mudah, cepat, dan menyenangkan (Hasbullah, 1995). Berikut ini akan dijelaskan secara singkat mengenai metode-metode pengajaran al-Qur'an.

\section{a. Metode Talaqqî}

Talaqqî secara bahasa berarti saling bertemu atau berhadapan. Metode talaqqî adalah metode mempelajari suatu ilmu secara langsung dengan seorang guru. 
Dalam pembelajaran al-Qur'an, metode talaqqî berarti seorang murid bertemu atau berhadapan langsung dengan gurunya sehingga ia tidak hanya mendengar lafazh al-Qur'an yang diucapkan oleh gurunya, tetapi juga melihat langsung bagaimana guru melafalkan lafazh tersebut dari mulutnya. Jadi dengan metode talaqqî ini seorang guru membenarkan bacaan santri secara langsung, baik makhârijul hurūf maupun sifat huruf dengan saling berhadapan (Abdurrohim, 2003).

Kelebihan metode ini ialah memudahkan pengajar memilih cara yang tepat dalam menyampaikan materi pembelajaran, karena dengan bertemu langsung antara guru dan santri, membuat guru lebih mudah mengenali kepribadian santri. serta metode ini boleh dilaksanakan secara individu atau kelompok. Sedangkan, kekurangan dari metode ini ialah tidak ada sistem yang jelas, dan tidak adanya buku penunjang untuk pembelajaran yang dimulai dari tahap awal atau pengenalan huruf hijâiyyah, berbaris fathah, kasrah, dhammah dan seterusnya.

b. Metode al-Baghdadiyah

Metode ini disebut dengan metode al-Baghdadiyah karena berasal dari Baghdad yang mulai muncul pada masa pemerintahan khalifah Bani Abbasyiah. Tidak diketahui dengan pasti siapa penyusunnya (Yunus, 1979). Metode alBaghdadiyah adalah metode yang tersusun secara berurutan dengan proses dieja atau diulang-ulang. Metode ini dikenal juga dengan sebutan metode alif, $b a$, ta, atau juga disebut dengan metode eja. Metode ini adalah metode yang paling lama muncul sampai berabad-abad dan metode yang pertama berkembang di Indonesia (Rusiana, 2015). Metode ini lahir melengkapi dari metode talaqqî, karena metode ini menggunakan sebuah buku pegangan untuk santri yang diawali dengan pengenalan huruf hijâiyyah. Metode ini dalam mempelajari huruf-huruf hijâiyyah dibaca secara berulang kali dan diikuti dengan lagu sederhana, sehingga anak mudah hafal dan tidak bosan, seperti yang dikemukakan
Mahmud Yunus, "Kebaikan sistem lama itu ialah karena pembelajaran itu diulang-ulang oleh anak- anak dengan lagu dan lagu itulah satu-satunya yang menarik mereka meskipun mereka tidak mengerti apa yang dilagukan" (Yunus, 1979).

Kelebihan metode ini ialah santri memiliki buku pegangan yang diajarkan secara bertahap dari pengenalan huruf hijâiyyah, huruf berbaris, menyambung huruf dan diakhiri dengan membaca juz amma'. Sedangkan, kekurangan dari metode ini ialah tidak dijelaskan bagaimana cara pengajaran dengan metode ini, tidak adanya pengajaran hukum tajwid, dan membutuhkan waktu yang lama karena menggunakan sistem eja yakni diulangulang dalam pembelajarannya (Yunus, 1979).

c. Metode Iqra'

Metode Iqra' ini disusun oleh ustadz As'ad Humam dari Yogyakarta. Metode Iqra' adalah suatu metode membaca alQur'an yang menekankan pada latihan membaca. Metode ini mempunyai buku panduan yang terdiri dari enam jilid dimulai dari tingkat yang sederhana, tahap demi tahap sampai pada tingkatan yang sempurna, dan di setiap jilid terdapat petunjuk pembelajarannya dengan maksud memudahkan setiap orang yang belajar maupun yang mengajarkan al-Qur'an. Metode Iqra' ini dalam prakteknya tidak membutuhkan alat yang bermacam-macam, karena ditekankan pada bacaan santri. Santri aktif membaca langsung tanpa dieja dan dapat latihan secara individual.

Kelebihan dari metode ini ialah tidak menggunakan sistem eja dan dalam pembelajarannya bukan guru yang aktif melainkan santri yang aktif dengan banyaknya latihan membaca. Sedangkan, kekurangan dari metode ini ialah bacaanbacaan tajwid tidak dijelaskan secara rinci pada enam jilid yang ada pada buku panduan Iqra' dan metode ini tidak dianjurkan untuk menggunakan irama murattal (Humam, 2000).

d. Metode Qira'ati

Metode Qira'ati adalah metode 
praktis belajar al-Qur'an yang disusun oleh ustadz K.H. Dahlan Salim Zarkasi pada tahun 1977 di Semarang, Jawa Tengah. Metode ini diperuntukkan untuk mengajar permulaan baca al-Qur'an yang dilengkapi bacaan tajwid untuk anak-anak agar dapat membaca al-Qur'an dengan baik (Zarkasi, 1997). Metode Qira'ati terdiri dari sepuluh jilid, yang mana pada masing-masing jilid terdapat petunjuk mengajar, yaitu (1) Mengajarkan dengan bacaan langsung atau tidak dieja, (2) Para guru cukup menjelaskan pokok pelajaran dilarang untuk menuntun bacaan santri, (3) Sistem Qira'ati adalah murid membaca sendiri dari jilid satu sampai sepuluh bahkan sampai membaca al-Qur'an, para guru cukup megawasi dan menjelaskan apa yang kurang, (4) Apabila murid dalam membaca masih banyak salah, maka diharuskan untuk mengulanginya kembali (Zarkasi, 1997).

Kelebihan metode ini adalah santri aktif dalam belajar membaca al-Qur'an, guru hanya menjelaskan pokok penjelasan dan metode ini mempunyai penjelasan mengenai hukum-hukum tajwid dan bacaan gharîb. Sedangkan, kelemahan dari metode ini ialah bagi santri yang tidak aktif akan semakin tertinggal, karena harus terus mengulang di halaman yang sama hingga bacaannya baik dan benar.

e. Metode Tartili

Metode Tartili adalah metode yang disusun oleh ustadz Syamsul Arifin AlHafidz, beliau adalah pengasuh Pondok Pesantren Darul Hidayah, Jember, Jawa Timur. Beliau awalnya merupakan koordinator Qira'ati se-Jawa dan Bali. Namun, Pada pertengahan tahun 2000 beliau menciptakan metode sendiri yang diberi nama "Metode Belajar Al-Qur'an Tartili".

Metode tartili terbilang lebih cepat dibandingkan metode lain karena buku panduannya hanya terdiri dari empat jilid, dan metode ini juga memperkenalkan metode menulis huruf Arab. Metode Tartili menggabungkan antara sistem klasikal dan sistem privat. Pada sistem klasikal, guru memberikan contoh dan murid menirukannya dan sistem klasikal juga membangun kedekatan emosional antara santri dan guru. Sedangkan sistem privat menitikberatkan pada pendalaman materi (Arifin, 2000). Kelebihan metode ini lebih ringkas dari dari metode sebelumnya, metode ini hanya memiliki empat jilid buku pegangan dan dilengkapi dengan hukum tajwid. Sedangkan, kekurangan metode ini ialah tidak adanya pengenalan bacaan gharîb.

f. Metode Tilawati

Metode tilawati disusun pada tahun 2002 oleh Tim yang terdiri dari Drs. H. Hasan Syadzili, K.H. Thohir Al-Aly, M.Ag, K.H. Masrur Masyhud, dan Drs. H. Ali Muafa. Metode ini awalnya dikembangkan di Pesantren Nurul Falah Surabaya. Metode ini menggunakan lagu rost dalam pembelajarannya, agar selain mampu membaca al-Qur'an dengan baik dan benar, santri juga dapat membaca al-Qur'an dengan berirama. Tilawati merupakan buku metode belajar membaca al-Qur'an yang terdiri dari enam jilid yang berisi mulai dari pengenalan dasar huruf al-Qur'an hingga mampu membaca al-Qur'an dengan baik dan benar. Di setiap jilid terdapat petunjuk dan pokok bahasan yang akan diajarkan dan dilengkapi dengan strategi pembelajaran dengan menggunakan pendekatan yang seimbang antara pembiasaan melalui klasikal dan kebenaran membaca melalui individual dengan teknik baca simak (Hasan, 2010).

Kelebihan dari metode ini ialah memiliki sistematika pembelajaran yang teratur dan jelas, pembelajarannya menggunakan irama lagu rost yang dinilai mudah dan meyenangkan, adanya buku panduan, dan adanya penjelasan singkat mengenai hukum bacaan dan bacaan gharîb. Sedangkan, kelemahannya ialah metode ini mengharuskan keaktifan santri dan guru, jadi bagi santri yang kurang aktif akan ketinggalan dari santri yang lainnya.

\section{g. Metode Ummi}

Metode ummi ialah metode pengajaran al-Qur'an yang disusun oleh ustadz Masrusi dan ustadz Yusuf MS. 
Pengajaran al-Qur'an dengan metode ini dimulai dari pengenalan huruf-huruf hijâiyah hingga lancar membaca al-Qur'an, yang disesuaikan berdasarkan tingkatan umur, jika santrinya anak-anak maka dari jilid satu hingga jilid enam, namun jika santrinya remaja atau dewasa maka hanya dengan tiga jilid buku saja, dan di setiap pembelajaran untuk anak-anak, remaja, dan dewasa juga dilengkapi dengan buku pegangan mengenai pengenalan tajwid dasar serta bacaan-bacaan gharîb (Masruri dan Yusuf, 2015).

Ummi merupakan pengertian dari kata ibuku. Pendekatan yang digunakan dalam pembelajaran al-Qur'an metode Ummi adalah pendekatan bahasa ibu. Adapun proses pembelajarannya, metode ini mengusung tiga prinsip yakni mudah, menyenangkan dan menyentuh hati (Masrusi dan Yusuf, 2013). Metode Ummi adalah suatu sistem yang terdiri dari tiga kompunen sistem, yaitu buku praktis metode Ummi, manajemen mutu metode Ummi, dan guru bersetifikat metode Ummi. Ketiga hal tersebut harus dimiliki dan digunakan secara simultan jika ingin mendapatkan hasil yang optimal dari metode ini. Pada setiap buku Ummi terdapat petunjuk umum mengajar metode Ummi dan pokok bahasan sesuai dengan jilid yang diajarkan, sehingga memudahkan setiap orang yang ingin belajar maupun yang mengajarkan dengan metode ini (Masruri dan Yusuf, 2013). Kelebihan metode ini ialah menggunakan pendekatan ibu yang bermottokan mudah, menyenangkan, dan menyentuh hati, metode ini juga memiliki sistematika yang jelas dan bagus. Sedangkan, kekurangannya ialah metode ini terlalu banyak memiliki buku pegangan yakni enam jilid, buku tajwid, dan buku bacaan gharîb yang pada setiap buku terdiri dari 40 halaman.

h. Metode At-Tibyan

Metode At-Tibyan adalah metode pembelajaran al-Qur'an hasil karya dari Syekh Abdurrahman Bakr. Metode ini dalam pembelajarannya menggunakan syair-syair atau nada dan menggunakan teknik tahajjî dengan bahasa Arab, sehingga santri mengetahui hukum-hukum yang ada pada bacaan dengan bahasa Arab. Dalam metode ini santri membaca dengan berulang-ulang sampai santri mengerti dan memahami materi pembelajaran yang telah disampaikan, dengan tujuan agar santri lebih mudah dalam membaca al-Qur'an dengan mengetahui tajwid ketika mengeja (Bakr, 1433).

Buku panduan metode At-Tibyan terdiri dari dua jilid. Adapun jilid pertama berisikan tentang pengenalan huruf hijâiyyah tunggal dan sambung, huruf yang berharakat fathah, kasrah, dhammah, hukum bacaan mad thabî' $\hat{\imath}$, pengenalan harakat tasydîd, sukun, fathatain, kasratain, dhammatain. Pada jilid terakhir memuat semua hukum bacaan secara lengkap. Selain itu juga di bagian bawah di beberapa halaman buku panduan terdapat cara mengeja kata dan kalimat yang terdapat di atasnya (Bakr, 1433).

Kelebihan metode ini ialah lebih cepat karena hanya memiliki dua jilid buku pegangan, dan penulisan pada bacaannya disesuaikan dengan tulisan al-Qur'an Rasm Usmani. Sedangkan kekurangannya ialah bagi yang tidak mengerti bahasa Arab akan susah memahami buku dari metode ini karena penjelasan pada bukunya menggunakan bahasa Arab.

2. Rumah-Rumah Tahfizh di Kota Banjarmasin: Profil, Program, dan Metode Pengajaran al-Qur'an

Lembaga tahfizh merupakan wadah atau tempat untuk seseorang yang ingin menghafal al-Qur'an agar hafalannya terkontrol terus menerus dan dapat dievaluasi. Ada beberapa lembaga tahfizh yang ada di Kota Banjarmasin, yaitu sekolah tahfizh, pondok tahfizh, TPA tahfizh, dan rumah tahfizh. Adapun yang dibahas dalam tulisan ini terbatas pada rumah-rumah tahfizh yang ada di Kota Banjarmasin. Rumah tahfizh yang dimaksud dalam penelitian ini ialah tempat untuk mempelajari dan menghafal al-Qur'an tanpa sistem asrama seperti halnya pondok pesantren. Ada empat kriteria rumah 
tahfizh dalam penelitian ini, diantaranya yaitu rumah tahfizh yang bertempat di Kota Banjarmasin, rumah tahfizh yang sudah berdiri lebih dari satu tahun, rumah tahfizh yang sudah memiliki struktur kepengurusan, dan rumah tahfizh yang memiliki santri lebih dari lima puluh orang. Berdasarkan kriteria dan data yang didapat oleh penulis, ada lima rumah tahfizh yang tersebar di Kota Banjarmasin, yaitu: Rumah Tahfizh al-Haramain, Rumah Tahfizh azZahra, Rumah Tahfizh Miftahul Ihsan, Rumah Tahfizh Qaryah Thayyibah, dan Rumah Tahfizh an-Nur. Kelima rumah tahfizh tersebut masing-masing berdiri sendiri meskipun antara satu rumah tahfizh dengan yang lainnya terdapat pengajar yang sama, dan beberapa rumah tahfizh sudah memiliki cabang di beberapa tempat.

\section{Rumah Tahfizh Al-Haramain}

Rumah Tahfizh al-Haramain berada di jalan Pekapuran Raya gang Seroja Rt. 17 Nomor 35, Banjarmasin Timur Kota Banjarmasin. Rumah Tahfizh a lHaramain didirikan pada tanggal 26 Maret 2014 oleh Ustadz H Sofyan Baderuddin, S.Pd.I, yang kemudian menjabat sebagai Ketua Yayasan al-Haramain (Mukminin, 2014).

Adapun struktur kepengurusan dari Rumah Tahfizh al-Haramain sebagai berikut:

Tabel 1:

Pengurus Rumah Tahfizh al-Haramain

\begin{tabular}{|l|l|}
\hline Ketua Yayasan & $\begin{array}{l}\text { H Sofyan Baderuddin, } \\
\text { S.Pd.I. }\end{array}$ \\
\hline $\begin{array}{l}\text { Kepala } \\
\text { Sekolah }\end{array}$ & M. Musthafa Kamil, S.Th.I. \\
\hline Sekretaris & Rijal Mukminin, S.Pd. \\
\hline $\begin{array}{l}\text { Penanggungjawab } \\
\text { Pembelajaran }\end{array}$ & $\begin{array}{l}\text { Fakhrie Hanief, MA., } \\
\text { Hendra Wahyudi, S.Pd.I., } \\
\text { Rijal Mukminin, S.Pd., dan } \\
\text { Norliani Safitri, S.Pd }\end{array}$ \\
\hline
\end{tabular}

(Sumber: Mukminin, 2014)

Latar belakang berdirinya rumah tahfizh al-Haramain ialah karena adanya keinginan dari Ustadz Sofyan untuk mengajarkan al-Qur'an kepada masyarakat, khususnya generasi muda agar di masa yang akan datang ada banyak orang yang bisa membaca al-Qur'an dengan baik dan benar serta mampu menghafal al-Qur'an. Keinginan tersebut didukung dengan banyaknya Sumber Daya Manusia (SDM) yang mampu mengajarkan al-Qur'an di kota Banjarmasin, seperti para sarjana dan alumni pondok pesantren yang sudah memiliki kompetensi dalam bidang alQur'an. Oleh karena itu, diperlukan tempat untuk melaksanakan niat mulia tersebut.

Tujuan didirikannya Rumah tahfizh al-Haramain ialah untuk mencetak dan melahirkan generasi yang hafizh/ hafizhah yang mengamalkan al-Qur'an dalam kehidupan sehari-hari, berbakti kepada orang tua, dan berakhlak mulia kepada sesame (Kamil, 2018). Untuk mencapai tujuan tersebut, Rumah Tahfizh al-Haramain memiliki visi dan misi. Visi Rumah Tahfizh al-Haramain adalah membentuk generasi Qur'ani yang berakhlak mulia. Adapun misi Rumah Tahfizh al-Haramain adalah: (1) Menyelenggarakan program tahsin dan tahfizh yang berbasis pada mutu; (2) Memberdayakan potensi keagamaan peserta didik yang sesuai dengan kebutuhan masyarakat; (3) Memberdayakan profesionalitas guru al-Qur'an; Meningkatkan kerjasama dengan berbagai pihak dalam rangka kemajuan lembaga tahfizh (Mukminin, 2014).

Rumah Tahfizh Al-Haramain memiliki cabang di tiga tempat, yaitu: (1) Rumah Tahfizh al-Haramain di Komplek Perdagangan jalan Kayu Tangi, Kelurahan Alalak Utara, Kecamatan Banjarmasin Utara, Kota Banjarmasin; (2) Rumah Tahfizh al- Haramain di jalan Rawa Sadewa, Beruntung Jaya, Kelurahan Pemurus Dalam, Kecamatan Banjarmasin Selatan, Kota Banjarmasin; (3) Rumah Tahfizh al- Haramain di jalan Antasan Raden Muara, Teluk Tiram Laut, Kecamatan Banjarmasin Barat, Kota Banjarmasin (Kamil, 2018).

Program pembelajaran al-Qur'an di Rumah Tahfizh al-haramain dilaksanakan dari hari Senin sampai hari Jum'at. Pada setiap hari ada tiga sesi atau kelompok. Pembagian tersebut berdasakan usia santri 
dan waktu pembelajarannya. Sesi pertama ialah santri yang berusia sekitar empat sampai delapan tahun. Pembelajarannya dimulai dari pukul 14:00-15:30 WITA. Sesi kedua ialah santri yang berusia sembilan sampai sepuluh tahun. Pembelajarannya dimulai dari pukul 15:30-17:45 WITA. Sesi ketiga merupakan santri yang berusia sebelas sampai dua puluh tahun ke atas. Pembelajarannya dimulai dari pukul 18:00-20:30 WITA (Mukminin, 2018).

Adapun guru/ tenaga pengajar di Rumah Tahfizh al-Haramain pada tahun 2018 ialah: Pada sesi pertama dengan Penanggung jawab Ustadzah Norliani Safitri, S.Pd dan pengajar-pengajarnya: (1) Ustadz Hendra Wahyudi, S.Pd.I; (2) Ustadz Rijal Mukminin, S.Pd; (3) Ustadz Ahmad Mustaien, M.H.I; (4) Ustadz Muhammad Zaini, Lc; (5) Ustadz Muhammad Jailani Hasan; (6) Ustadz Ahmad Arifin; (7) Ustadz Kastalani; (8) Ustadz Fadliannor; (9) Ustadz Muhammad Faisal; (10) Ustadzah Siti Annisah; (11) Ustadzah Muthmainnah; (12) Ustadzah Fatimatuzzahra; (13) Ustadzah Nisrina Yumna; (14) Ustadzah Jamilatul Qiftiyah; (15) Ustadzah Sa'diah.

Sesi kedua dengan Penanggung jawab Ustadz Rijal Mukminin, S.Pd dan pengajar-pengajarnya: (1) Ustadz Hendra Wahyudi, S.Pd.I; (2) Ustadz Ahmad Mustaien, M.H.I; (3) Ustadz Muhammad Zaini, Lc; (4) Ustadz Muhammad Jailani Hasan; (5) Ustadz Ahmad Arifin; (6) Ustadz Muhammad Faisal; (7) Ustadz Muhammad Samman.; (8) Ustadzah Norliani Safitri, S.Pd; (9) Ustadzah Siti Annisah; (10) Ustadzah Muthmainnah; (11) Ustzah Fatimatuzzahra; (12) Ustadzah Nisrina Yumna; (13) Ustadzah Jamilatul Qiftiyah; (14) Ustadzah Siti Suci Renanda; (15) Ustadzah Yuyuk Sugiarti Ningsih; (16) Ustadzah Fatmawati; (17) Ustadzah Lailatul Farah.

Sesi ketiga dengan Penanggung jawab Ustadz Fakhrie hanif, MA dan Ustadz Hendra Wahyudi, S.Pd.I dan pengajar-pengajarnya: (1) Ustadz H. Faisal Baderuddin Balli, S.Sos.I; (2) Ustadz
Husnul Yakin; (3) Ustadz Sanudin Baderuddin Balli; (4) Ustadz Rijal Mukminin, S.Pd; (5) Ustadz Akhmad Mustaien, M.H.I; (6) Ustadz Muhammad Zaini, Lc; (7) Ustadz Latip Munadi; (8) Ustadz Heriyadi; (9) Ustadz Ahmad Arifin; (10) Ustadzah Murtajiah, S.Th.I; (11) Ustadzah Zulvia Kamiliah; (12) Ustadzah Maimunah; (13) Ustadzah Fatimah Azzahra; (14) Ustadzah Norliani Safitri, S.Pd; (15) Ustadzah Fina Kamiliah; (16) Ustadzah Misnawati (Mukminin, 2018).

Setiap satu pengajar terdapat sepuluh sampai lima belas santri bahkan bisa jadi sampai depalan belas santri. Program wajib yang ada di Rumah Tahfizh Al-Haramain ialah belajar membaca (bagi yang belum bisa), memperbaiki bacaan alQur'an (tahsin al-Qur'an), menghafal alQur'an (tahfizh al-Qur'an), dan mengulang hafalan (muraja'ah) (Kamil, 2018). Berikut ini daftar kegiatan di Rumah Tahfizh alHaramain:

Tabel 2: Daftar Kegiatan di Rumah Tahfizh al-Haramain

\begin{tabular}{|c|l|l|}
\hline No. & Waktu & Kegiatan \\
\hline 1 & 5 Menit & Pembukaan \\
\hline 2 & $25-30$ Menit & Muraja'ah dan Tahfizh \\
\hline 3 & $25-30$ Menit & Tahsin \\
\hline 4 & 10 Menit & Praktik Salat \\
\hline 5 & 5 Menit & Doa dan Penutup \\
\hline
\end{tabular}

Pada awal berdirinya, Rumah Tahfizh al-Haramain belum mempunyai metode khusus yang digunakan dalam pengajaran al-Qur'an selain metode talaqqi. Selama kurang lebih enam bulan berikut, Rumah Tahfizh al-Haramain menggunakan metode Ummi karya sebagai rujukan dalam belajar membaca dan memperbaiki bacaan al-Qur'an.

Alasan dipilihnya metode Ummi sebagai metode pembelajaran al-Qur'an di Rumah Tahfizh al-Haramain, ialah: Pertama, metode Ummi mempunyai motto mudah, menyenangkan dan menyentuh hati, sehingga membuat santri senang dan tidak bosan dalam belajar.; Kedua, metode Ummi mempunyai sistem yang bagus dan jelas, karena tujuan yang dikehendaki dan target yang ingin dicapai 
dari metode Ummi sudah tersistematika dengan jelas dengan cara yang sudah ditentukan dalam metode tersebut. Pada setiap buku atau jilid metode Ummi sudah terdapat petunjuk umum mengajar dan pokok bahasan sesuai dengan jilid yang diajarkan, sehingga memudahkan bagi setiap orang yang belajar dan mengajarkannya.; Ketiga, Rumah Tahfizh al-Haramain sudah menjalin kerjasama dengan pihak pusat di Surabaya yang bertanggungjawab mengontrol dan mengawasi dari berlangsungnya setiap pembelajan, sehingga metode ini sudah menjadi kurikulum dari Rumah Tahfizh al-Haramain (Kamil, 2018).

\section{Rumah Tahfizh Az-Zahra:}

Rumah Tahfizh Az-Zahra berada di jalan Pramuka Komplek Melati Indah Rt. 10, Banjarmasin Timur, Kota Banjarmasin. Rumah Tahfizh Az-Zahra didirikan pada tanggal 28 April 2014 oleh Ustadz H. Ramadansyah sebagai pimpinan Rumah Tahfizh Az-Zahra dan Ustadz Drs. H. M. Saleh Yusran sebagai kepala sekolah Rumah Tahfizh Az-Zahra (Yusran, 2018).

Adapun struktur kepengurusan dari Rumah Tahfizh Az-Zahra adalah sebagai berikut:

\section{Tabel 3:}

Pengurus Rumah Tahfizh az-Zahra

\begin{tabular}{|l|l|}
\hline Ketua Yayasan & H. Ramadansyah \\
\hline Kepala Sekolah & Drs. H. M. Saleh Yusran \\
\hline Sekretaris & Mar'atun Shalehah \\
\hline Bendahara & Ahmad Baihaqi, S.Pd.I \\
\hline Pengajaran & $\begin{array}{l}\text { Abdurrahim, Rif'ah } \\
\text { Fadhiylah, dan Haryati }\end{array}$ \\
\hline
\end{tabular}

(Sumber: Yusran, 2018)

Latar belakang berdirinya Rumah

Tahfizh Az-Zahra ialah minimnya rumah tahfizh di Banjarmasin saat itu, padahal keberadaan rumah tahfizh sangat dibutuhkan oleh masyarakat untuk tempat pengajaran dan menghafal al-Qur'an. Selain itu, menurut Saleh Yusran yang sering mengikuti Musabaqah Tilawatil Qur'an (MTQ), masih banyak kekosongan dan kekurangan peserta dalam cabang tahfizh al-Qur'an. Oleh karena itu, muncul inisiatif untuk mendirikan rumah tahfizh agar nantinya santri yang ada di Rumah Tahfizh Az-Zahra bisa menjadi penghafal al-Qur'an yang kemudian bisa turut serta mengikuti berbagai Musabaqah al-Qur'an (Yusran, 2018).

Sebagai arah pengembangan Rumah Tahfizh az-Zahra, maka telah dirumuskan Visi dan Misi. Visi Rumah Tahfizh az-Zahra yaitu: Mencetak generasi muda yang mampu menghafal al-Qur'an dengan bacaan yang baik dan benar. sedangkan Misi dari Rumah Tahfizh Qur'an az-Zahra ialah: (1) Membudayakan menghafal al-Quran bagi masyarakat; (2) Mengembangkan metodologi menghafal alQuran; (3) Melahirkan kader-kader hafizh/hafizhah; (4) Membangun kerjasama dengan berbagai pihak untuk kajian ilmu alQuran (Yusran, 2018).

Proses pembelajaran di Rumah Tahfizh Az-Zahra dilaksanakan dari hari Senin sampai hari Jum'at, sejak pukul 16:30-20:30 WITA. Rumah tahfizh ini mempunyai beberapa program pengajaran al-Qur'an, yaitu menyelenggarakan metodologi menghafal al-Qur'an, pembelajaran tartil al-Qur'an, pembelajaran tilawah Qur'an, dan pembelajaran ilmu tajwid dan fashahah (Yusran, 2018). Adapun nama-nama pengajarnya ialah Ustadz Drs. H. M. Saleh Yusran, Ustadz Ahmad Baihaqi, S.Pd.I, Ustadz Abdurrahim, Ustadzah Mar'atun Shalehah, Ustadzah Rif'ah Fadhiylah, dan Ustadzah Haryati.

Di rumah tahfizh ini tidak hanya kegiatan menghafal al-Qur'an tetapi juga ada pelajaran-pelajaran tambahan seperti bahasa Arab, ibadah salat, dan kesenian. Berikut jadwal kegiatan di malam hari yang telah ditentukan:

1. Hari Senin atau malam Selasa : Tahsin (Tajwid dan Tartil)

2. Hari Selasa atau malam Rabu : Tilawah

3. Hari Rabu atau malam Kamis : Bahasa Arab

4. Hari Kamis atau malam Jum'at: Ibadah Salat

5. Hari Jum'at atau malam Sabtu : 
Kesenian

Pengajaran al-Qur'an di Rumah

Tahfizh Az-Zahra menggunakan metode talaqqî, yakni materi kajian al-Qur'an langsung disampaikan oleh ustadz/ ustadzahnya kepada seluruh santri, kemudian santri diajarakan untuk mempraktekkan bacaan al-Qur'an dengan tartil. Jadi, pengajaran al-Qur'an di rumah tahfizh ini merupakan gabungan dari pembelajaran tajwid dan tartil. Pembelajaran tajwid merupakan proses pemberian materi atau penjelasan tentang hukum-hukum yang terdapat pada bacaan al-Qur'an agar santri mengetahui cara membaca al-Qur'an dengan baik dan benar. Sedangkan pembelajaran tartil merupakan praktik secara langsung pada bacaan alQur'an dengan cara yang baik dan benar atau sesuai dengan tajwid (Yusran, 2018).

\section{Rumah Tahfizh Miftahul Ihsan}

Rumah Tahfizh Miftahul Ihsan berada kawasan masjid Agung Miftahul Ihsan di jalan Pangeran Antasari, Banjarmasin Tengah, Kota Banjarmasin. Rumah Tahfizh ini didirikan pada bulan September 2014 dan dibina oleh Dr. Agus Salim, M.M.Pd.

Adapun struktur kepengurusan Rumah Tahfizh Miftahul Ihsan sebagai berikut:

Pembina : Dr. Agus Salim, M.Pd.

Kepala Sekolah : M. Taufik Akbar, S.Pd.I.

Sekretaris : Jubaidah, S.Pd.

Bendahara :Salmiah

Bag. Pengajaran : Khairunnisa, S.Sos.

Sumber : Akbar, 2018.

Latar belakang berdirinya rumah tahfizh ini ialah karena pada saat itu belum banyak ditemukan rumah tahfizh di kota Banjarmasin, padahal banyak anak-anak yang memiliki potensi untuk menghafal alQur'an dan jug a ada keinginan dari orang tua agar didirikan lembaga tahfizh. Sebelumnya, di kawasan masjid Mitahul Ihsan sudah ada Taman Pendidikan AlQur'an (TPA) yang dilaksanakan setiap sore. Sebagai pengembangan pembelajaran, maka dibangunlah Rumah Tahfizh Miftahul Ihsan yang dilaksanakan pada malam hari untuk mengembangkan potensi anak dalam menghafal al-Qur'an (Akbar, 2018)

Tujuan awal didirikannya Rumah Tahfizh Miftahul Ihsan ialah menjadikan lembaga atau wadah bagi anak-anak untuk belajar al-Qur'an khususnya untuk menghafal al-Qur'an yang mengacu pada visi dan misi rumah tahfizh Miftahul Ihsan. Visinya adalah melahirkan generasi alQur'an yang gemar membaca, menghafal dan mengamalkan al-Qur'an. Sedangkan misinya adalah:

Menumbuhkembangkan kecintaan terhadap al- Qur'an; (2) Memperbaiki bacaan alQur'an; (3) Menikmati hafalan dan muraja'ah; (4) Memberikan Pemahaman terhadap al-Qur'an; (5) Menciptakan suasana Qur'ani (Akbar, 2017).

Proses pembelajaran di Rumah Tahfizh Miftahul Ihsan dilaksanakan dari hari Senin sampai dengan hari Kamis, sejak pukul 18:00-21:00 WITA. Rumah tahfizh ini mempunyai program-program sebagai berikut, yaitu tahsin bacaan alQur'an, menghafal al-Qur'an dengan metode Tikrar, memberikan motivasi menghafal dan muraja'ah, karantina tahfizh al-Qur'an, wisuda tahfizh al-Qur'an, dan pembelajaran tausiyah (Akbar, 2017).

Adapun waktu belajar al-Qur'an santri dalam setiap pertemuan, dengan rincian secara berikut:

Tabel 4: Kegiatan di Rumah Tahfizh Miftahul

\begin{tabular}{|c|l|l|}
\hline No. & Waktu & Pembelajaran \\
\hline 1 & 5 Menit & Pembukaan \\
\hline 2 & $20-25$ Menit & $\begin{array}{l}\text { Muraja'ah } \\
\text { Menghafal Bersama }\end{array}$ \\
\hline 3 & $15-20$ Menit & Salat Magrib \\
\hline 4 & $15-20$ Menit & Tahsin al-Qur'an \\
\hline 5 & 45 Menit & Tahfizh dan Setoran \\
\hline 6 & $15-20$ Menit & Salat Isya \\
\hline 7 & $5-10$ Menit & Tausiah atau Motivasi \\
\hline 8 & 5 Menit & Doa dan Penutup \\
\hline
\end{tabular}

Dalam Pembelajaran al-Qur'an di Rumah Tahfizh Miftahul Ihsan, santri dibagi menjadi dua kelompok, yaitu 
kelompok tahfizh cilik dan tahfizh remaja. Kelompok pertama disebut dengan tahfizh cilik karena di kelompok ini para santrinya baru berusia sekitar empat sampai tujuh tahun dan sebagian besar santri belum mengenal huruf-huruf hijâiyah dengan pengajar Ustadzah Salmiah. Sedangkan kelompok kedua disebut dengan tahfizh remaja karena santri berusia sekitar delapan sampai lima belas tahun dan sebagian besar sudah mengetahui huruf-huruf hijâiyyah dengan bacaan yang masih kurang lancer. Kelompok ini diajar oleh Ustadz M. Taufik Akbar, S.Pd.I, Ustadzah Khairunnida, S.Sos, dan Ustadzah Jubaidah S.Pd. (Akbar, 2018).

Adapun metode pengajaran alQur'an yang digunakan di Rumah Tahfizh Miftahul Ihsan pada awal berdirinya ialah metode Talaqqî yaitu metode mempelajari al-Qur'an secara langsung dengan gurunya. Jadi seorang santri berhadapan langsung dengan gurunya sehingga ia mendengar dan melihat pengucapan lafazh al-Qur'an yang dibaca oleh gurunya (Abdurohim, 2018).

Pada tahun 2017, kurikulum Rumah Tahfizh Miftahul Ihsan, khususnya pada kajian tahsin al-Qur'an itu menggunakan metode Tilawati untuk santri tahfizh cilik dan Metode At-Tibyan untuk santri tahfizh remaja. Adapun alasannya yang pertama mengunakan metode Tilawati untuk tahfizh cilik, karena sebagian besar santri belum mengenal huruf hijâiyyah, oleh sebab itu pembelajaran tahsin menggunakan metode Tilawati karena metode tilawati ini mengajarkan mulai dari awal dan bertahap yakni mulai dari pengenalan huruf hijâiyyah, huruf yang berbaris fathahkasrah-dhammah, huruf sambung, dan seterusnya. Metode Tilawati menggunakan lagu rost pada setiap pengenalan huruf, bacaan pendek atau panjang dan seterusnya. Sehingga hal tersebut membiasakan santri agar pada saat membaca al-Qur'an dengan bacaan yang baik dan benar sekaligus berirama. Serta santri yang masih terbilang anak-anak pun menyukai dan bersemangat saat belajar dengan lagu tersebut. Metode Tilawati mempunyai tiga teknik yaitu guru membacakan santri mendengarkan, guru membacakan santri mengikuti, dan guru dan santri bersama-sama membacakan. Sehingga dari teknik itu saja santri sudah mengulang bacaan tiga kali, semakin banyak mengulang semakin santri mengenal atau mengingat huruf-huruf hijâiyyah. Sedangkan alasan digunakan metode AtTibyan ialah karena adanya pengajar yang berkompetensi dalam pengajaran al-Qur'an metode At-Tibyan, dan setelah melihat hasil evaluasi dari pengajaran program tahsin menggunakan metode At- Tibyan. Metode ini dinilai efektif dan kemajuan santri dalam membaca al-Qur'an dinilai cepat (Akbar, 2018)

\section{Rumah Tahfizh Qaryah Thayyibah}

Rumah Tahfizh Qaryah Thayyibah berada di jalan Perdagangan komplek HKSN Permai Blok B7 Rt. 35 Rw. 05 Alalak Utara, Banjarmasin Utara, kota Banjarmasin. Rumah Tahfizh Qaryah Thayyibah didirikan pada tanggal 16 Juni 2016 oleh H. Anwar Hadimi, S.E. Adapun struktur kepengurusan dari Rumah Tahfizh Qaryah Thayyibah adalah sebagai berikut:

Pembina : H. Anwar Hadimi, S.E H. Irhamsyah Safari, dan H. Aspiani, Lc.

Kepala Sekolah : Taufiqurrahman, S.Th.I. Sekretaris : Rahmat Hidayat, SH.

Bendahara : Rafli Pratama.

Humas : H. Mahyuni.

Latar belakang berdirinya rumah tahfizh ini bermula dari gagasan yang diajukan oleh salah seorang yang berdomisili di daerah jalan Perdagangan, Banjarmasin utara, Banjarmasin, yakni $\mathrm{H}$. Anwar Hadimi. Ia mempunyai mimpi atau keinginan untuk membangun sebuah lembaga pendidikan berbasis al-Qur'an di lingkungan tersebut (Taufiqurrahman dan Hidayat, 2018). Selain itu, ada juga dorongan dari masyarakat yang berharap anak-anak mereka yang sudah menyelesaikan program belajar mengaji yang diadakan oleh BKPRMI (Badan 
Komunikasi Pemuda Remaja Masjid Indonesia), supaya bisa melanjutkan pembelajaran al-Qur'an ke jenjang berikutnya. Akhirnya, didirikanlah sebuah Lembaga Tahfizh Qaryah Thayyibah dan diresmikan pada tanggal 16 juni 2016 yang sekarang namanya berubah menjadi Rumah Tahfizh Qaryah Thayyibah (Taufiqurrahman dan Hidayat, 2018).

Sebagaimana rumah tahfizh lainnya, Rumah Tahfizh Qaryah Thayyibah juga mempunyai visi dan misi. Adapun visi dari Rumah Tahfizh Qaryah Thayyibah ialah menciptakan generasi Qur'ani yang diharapkan pada tahun 2030 setiap rumah terdapat satu orang hafizh/ hafizhah. Adapun misi dari Rumah Tahfizh Qaryah Thayyibah adalah menyelenggarakan program tahsin, program tahfizh, program tilawah dan program karantina tahfizh (Taufiqurrahman dan Hidayat, 2018).

Pada tahun 2018, Rumah Tahfizh Qaryah Thayyibah sudah memiliki cabang tahfizh di beberapa lembaga di Kota banjarmasin, yaitu Panti Asuhan Yayasan Ashabul Kahfi, Panti Asuhan Sentosa, Panti Asuhan Al-Amin Putri dan Putra, Panti Asuhan Al-Muhajirin, Panti Asuhan Aisiyah, Panti Asuhan Al-Ihsan, Panti Asuhan Harapan Ibu dan Panti Asuhan Muhammadiyah 3 yang semuanya merupakan lembaga binaan langsung dari Rumah Tahfizh Qaryah Thayyibah, dari segi pembinaan SDM, teknik pembelajaran, hingga manejemen keuangan. Hal ini sesuai dengan arahan H. Anwar Hadimi, S.E. selaku pembina Rumah Tahfizh Qaryah Thayyibah (Taufiqurrahman dan Hidayat, 2018).

Proses pembelajaran di Rumah Tahfizh Qaryah Thayyibah dilaksanakan pada hari Senin sampai hari Sabtu, sejak pukul 16:00-18:00 WITA. Rumah tahfizh ini mempunyai tiga program, yaitu: program tahsin, program tahfizh, dan program karantina tahfizh. Rumah Tahfizh Qaryah Thayyibah dalam pengelompokan belajar semua santri, seluruh pesertanya dibagi atas tiga kategori yaitu: kategori tahfizh ikhwan/ akhwat, tahsin ikhwan/ akhwat dan tilawah
(Taufiqurrahman dan Hidayat, 2018). Adapun waktu belajar al-Qur'an santri dalam setiap pertemuan adalah 5 Menit pembukaan, 100-110 menit tahfizh dan tahsin al-Qur'an, serta doa dan penutup.

Kajian tahsin intensif ikhwan di Rumah Tahfizh Qaryah Thayyibah menggunakan metode Talaqqî yang menggunakan buku rujukan "Panduan Tahsin Tilawah Metode Rasm Utsman, karya H. Ahmad Muzzammil MF alHafizh". Alasan penggunaan buku ini karena mudah dalam pembelajarannya, diantaranya buku ini tidak menekankan santri untuk hafal nama-nama hukum tajwid, buku ini mengajarkan tentang kode-kode atau tanda penulisan yang ada di dalam alQur'an Rasm Utsmani. Jadi santri hanya perlu mengingat kode-kode yang ada di dalam aturan penulisan al-Qur'an Rasm Utsmani dengan praktik membaca bacaan yang ada pada buku tersebut dengan bimbingan langsung oleh gurunya. Selain mudah, santri juga akan terbiasa membaca al-Qur'an dengan tulisan Rasm Utsmani (Shahibi, 2018).

Berbeda dengan ikhwan, Kajian tahsin intensif akhwat di rumah tahfizh ini menggunakan metode Ummi yakni dengan pelaksanaan pembelajaran al-Qur'an sesuai sistematika yang ada pada metode Ummi. Pengajarannya dengan dua tahap yaitu klasikal peraga yang menggunakan alat peraga dan baca simak yang menggunakan buku dari Metode Ummi. Adapun alasan menggunakan metode Ummi karena metode ini merupakan kompetensi dari pengajar dan santri akhwat cenderung menyukai hal yang mudah, menyenangkan, dan menyentuh hati sesuai dengan motto pembelajaran yang ada pada metode Ummi.

\section{Rumah Tahfizh An-Nur}

Rumah tahfizh An-Nur berada di jalan Pramuka Rt. 09 Rw. 01 No. 10 Kelurahan Pemurus Luar, Kecamatan Banjarmasin Timur, Kota Banjarmasin. Rumah Tahfizh An-Nur didirikan pada tanggal 08 April 2017 oleh Ustadz Fakhrie Hanief, S.Th.I, MA. Adapun struktur 
kepengurusan Rumah Tahfizh An-Nur adalah sebagai berikut:

Ketua Yayasan : Hj. Nor Hani.

Kepala Sekolah : Fakhrie Hanief, MA.

Wakil

: Ahmad Fauzi, S.Pd.I

Sekretaris : Ridha puady.

Bendahara : Zainal Aqli, S.Th.I.

Latar belakang berdirinya rumah tahfizh ini ialah karena adanya rasa prihatin dari para pendiri dengan banyaknya anak-anak yang tidak atau belum bisa membaca al-Qur'an dengan baik dan benar, sehingga ada keinginan untuk memberantas buta huruf al-Qur'an. Untuk itu, diperlukan lembaga atau wadah agar anak-anak dapat belajar al-Qur'an. Keinginan tersebut ternyata mendapat dukungan dari para orang tua yang ingin anaknya menjadi hafizh al-Qur'an (Hanief, 2018).

Rumah Tahfizh An-Nur memiliki visi dan misi. Visinya ialah melahirkan huffazh yang unggul dan bertakwa. Sedangkan misinya yaitu: (1) Melaksanakan Pendidikan dan Pengajaran al-Qur'an secara bekesinambungan; (2) Mengembangkan wawasan al-Qur'an peserta didik berdasarkan dasar-dasar ajaran Islam; (3) meningkatkan profesionalitas pengajar al-Qur'an dalam berbagai bidang; (4) Membangun kerjasama dengan berbagai pihak dalam rangka pengembangan lembaga tahfizh (Hanief, 2018).

Proses pembelajaran di Rumah Tahfizh An-Nur hanya dilaksanakan tiga hari dalam sepekan yakni pada hari Selasa, Kamis, dan Minggu, pukul 18:00-20:30 WITA, dengan kurikulum berbasis tahsin, tahfizh dan berwawasan keislaman. Rumah Tahfizh An-Nur mempunyai program kegiatan yaitu tahsin al-Qur'an, tahfizh alQur'an, tilawah al-Qur'an, ta'lim harian (fun tajwid, fiqh praktis dan hadis hadis/ akhlak), dan program Ahlul Qur'an Ahad Kamilah (Percepatan dan pemantapan hafalan).

Kajian tahfizh dan tahsin di Rumah Tahfizh An-Nur dibagi kepada tiga kelompok, yaitu kelompok Mubtadi', Mutawassith, dan Mahir. Kelompok
Mubtadi' adalah kelompok tingkat pemula dengan dasar-dasar membaca al-Qur'an, yakni mereka yang belum mampu membaca al-Qur'an dengan baik dan benar, kelompok ini belum sepenuhnya siap untuk menghafal al-Qur'an. Adapun pengajar di kelompok ini ialah Ustadz Ahmad, S.Th.I, Ustadz Abdurrahman, Ustadz M. Nor Asry, Ustadz Ahmad Hafiz, Ustadz Zainal Aqli, Ustadz Fikri Haikal, Ustadz Ridha Puadi, Ustadzah Mukhlisah Suriani, S.Pd, Ustadzah Fitriani, S.Th.I, Ustadzah Jamidah, S.Th.I, Ustadzah Noor Habibah, Ustadzah Halimah, Ustadzah Nurul Hikmah, dan Ustadzah Rahma Aliya.

Kelompok Mutawassith adalah kelompok tingkat menengah dengan memperbanyak tilawah dan menghafal, yakni mereka yang selesai tingkat mubtadi', dan fokus memperbanyak tilawah sebagai upaya pembiasaan dalam membaca alQur'an agar bacaan baik dan benar, dan menghafal dengan target tertentu. Adapun pengajar di kelompok ini ialah Ustadz Rizky Wahyudi, Ustadzah Mariatul Qibtin, dan Ustadzah Purnama.

Kelompok yang terakhir, Mahir Tahsin adalah tingkat atas dengan pembelajaran fokus pada menghafal, karena mereka yang ada di kelompok ini sudah mampu membaca al-Qur'an dengan baik dan benar serta sepenuhnya siap untuk menghafal al-Qur'an. Adapun pengajar di kelompok ini ialah Ustadz Ahmad Fauzi, Ustadzah Desi Helma Permata, dan Ustadzah Masyitah Annajah (Hanief, 2018).

Setiap guru mengajar dua belas hingga lima belas santri. Adapun waktu belajar al-Qur'an santri dalam setiap pertemuan sebagai berikut:

Tabel 5. Kegiatan di Rumah Tahfizh an-Nur

\begin{tabular}{|c|l|l|}
\hline No. & Waktu & Pembelajaran \\
\hline 1 & 5 Menit & Pembukaan \\
\hline 2 & $20-25$ Menit & Ta'lim Harian \\
\hline 3 & $15-20$ Menit & Salat Magrib \\
\hline 4 & $15-20$ Menit & Tahfizh \\
\hline 5 & 30 Menit & Tahsin \\
\hline 6 & $10-15$ Menit & Salat Isya \\
\hline 7 & 5 Menit & Doa dan Penutup \\
\hline
\end{tabular}


Dalam pembelajaran al-Qur'an, Rumah Tahfizh an-Nur menggunakan metode Tartili karya ustadz Syamsul Arifin Al-Hafidz yang direvisi oleh Pondok Pesantren Tahfizh Al-Qur'an AdDahlaniah. Alasan digunankannya metode tartili sebagai kurikulum dalam mengajarkan al-Qur'an ialah karena metode ini dinilai cepat, tepat, dan menyenangkan (Hanief, 2018).

\section{PENUTUP}

Dari pembahasan tersebut, dapat disimpulkan bahwa:

Pertama, ada beberapa rumah tahfizh di kota Banjarmasin pada tahun 2018 yang sudah berdiri lebih dari satu tahun dan mempunyai santri lebih dari lima puluh orang, yaitu: rumah tahfizh al-haramain, rumah tahfizh az-zahra, rumah tahfizh miftahul ihsan, rumah tahfizh qaryah thayyibah, dan rumah tahfizh an-nur. Kedua, rumah-rumah tahfizh tersebut mempunyai program pembelajaran al-Qur'an yang sudah terjadwal. Selain pengajaran al-Qur'an, ada juga program tambahan seperti praktik salat, bahasa Arab, dan kesenian Islami. Ketiga, semua rumah tahfizh tersebut, mempunyai metode dalam pengajaran al-Qur'an. Ada yang menggunakan metode ummi; metode talaqqi; metode tilawati; dan metode attibyan.

\section{DAFTAR PUSTAKA}

Abdurrohim, Acep Iim. (2003). Panduan Ilmu Tajwid Lengkap. Bandung: Diponegoro.

Akbar, M. Taufik. (2017). Profil Tahfizh AlQur'an Miftahul Ihsan. Banjarmasin: Tahfizh Al-Qur'an Miftahul Ihsan.

Ali al-Makky, Hisyam bin Mahrus. (2013). Bimbingan Tahsin Tilawah AlQur'an. Solo: Zamzam.

Arifin, Syamsul. (2000). Metode Belajar Al-Qur'an Tartili. Jember: Pondok Pesantren Darul Hidayah.

Bakr, Abdurrahman. (1433). At-Tibyân fi Itqân Al-Qirâ'ah bi Al-Qur'ân. Madinah: Al-Fath ar-Rabbani.

Hanief, Fakhrie. (2018). Profil Rumah
Tahfizh An-Nur. Banjarmasin: Rumah Tahfizh An-Nur.

Hasan, Abdurrohim, dkk. (2010). Strategi Pembelajaran Al-Qur'an Metode Tilawati. Surabaya: Pesantren Nurul Falah.

Hasbullah. (1995). Sejarah Pendidikan Islam di Indonesia: Lintasan Sejarah Pertumbuhan dan Perkembangan, Jakarta: PT. Raja Grafindo Persada.

Humam, As'ad. (2000). Buku Iqra Cara Cepat Belajar Membaca Al-Qur'an. Yogyakarta: Balai Litbang LPTQ Nasional Team Tadarus AMM,.

Masruri dan A. Yusuf MS. (2015). Modul Sertifikasi Guru Al-Qur'an Metode Ummi. Surabaya: Ummi Foudation.

------. (2013). Ummi. Surabaya: Lembaga Ummi Foundation.

Mukminin, Rijal. (2014). Profil Rumah Tahfizh Al-Haramain. Banjarmasin: Rumah Tahfizh Al-Haramain.

Rusiana. (2015). "Efektivitas Pembelajaran Membaca Al-Qur'an dengan Metode Ummi di SDIT Ukhuwah Banjarmasin," Skripsi. Banjarmasin: Fakultas Tarbiyah dan Keguruan IAIN Antasari .

Taufiqurrahman dan Rahmat Hidayat. (2018). Profil Rumah Tahfizh Qaryah Thayyibah. Banjarmasin: Rumah Tahfizh Al-Haramain.

Yunus, Mahmud. (1979). Sejarah Pendidikan Islam di Indonesia. Jakarta: Mutiara.

Yusran, M. Saleh. (2018). .Profil Rumah Tahfizh Az-Zahra. Banjarmasin: Rumah Tahfiz Az-Zahra. 
Jurnal Tarbiyah: Jurnal Ilmiah Kependidikan

Vol. 8 No. 1 Januari - Juni 2019 (39-52) 